Dereje Teklemariam, Azadi, H., Nyssen, J., Mitiku Haile, Witlox, F., 2015.

Transnational land deals: Towards an inclusive land governance framework.

Land Use Policy, 42: 781-789. (IF: 3.134)

\title{
Transnational land deals: Towards an inclusive land governance framework
}

Dereje Teklemariam ${ }^{\text {a,b }}$, , Hossein Azadi ${ }^{\text {a c, }{ }^{*}, \text { Jan Nyssen }^{\text {a }} \text {, Mitiku Haile }}{ }^{\text {d, Frank Witlox }}{ }^{\mathrm{a}}$

${ }^{\mathrm{a}}$ Department of Geography, Ghent University, Belgium.

${ }^{\mathbf{b}}$ Department of Management, Mekelle University, P.O.Box 451, Mekelle, Ethiopia.

${ }^{\mathrm{c}}$ Centre for Environmental Sciences, Hasselt University, Agoralaan Building D, 3590

Diepenbeek, Belgium.

${ }^{\mathrm{d}}$ Department of LaRMEP, Mekelle University, P.O.Box 231, Mekelle, Ethiopia.

"Corresponding authors at: Department of Geography, Ghent University, Belgium.Tel.: +32 09 26446 95; fax: +32 0926449 85.E-mail addresses:

DerejeTeklemariam.Gebremeskel@UGent.be (Dereje T.), hossein.azadi@ugent.be (H. Azadi).

\begin{abstract}
The literature on global land deals or land acquisition has extensively described the possible drivers, trajectories, and their impacts. In addition, the concept of a 'land grab' per se is heavily contested and viewed as a work in progress. Many have argued on the topic of inclusive land deals without addressing which groups of stakeholders are vested with particular powers and interests in the deals. After reviewing this phenomena in contemporary global land deals and the stakeholder theory of management developed in the 1980s, this paper proposes a conceptual land deal framework. Accordingly, the actors in land deals are characterised and disaggregated into
\end{abstract}


seven generic groups, i.e., "inactive", “discretionary", "exigent", "dominant", “dangerous", "dependent", and "definitive". The paper concluded that to address the governance challenges in land deals, a need exists to resolve conceptualisation deficiencies related to inclusive land deal frameworks. Thus, this work suggests that extending the stakeholder theory of management to the global governance of transnational land acquisition can significantly aid in resolving conceptualisation limitations for inclusive transnational land deals. Hence, a new inclusive land deal framework was developed that attempts to integrate the biophysical environment, stakeholders, governance, and institutions. Furthermore, this paper recommends that contextualisation of the suggested "land deal power-interest clustering (LD-PIC)" and "legitimacy-interest-power (LIP)" frameworks to those already signed and ongoing land deals using real-world data is a timely matter.

Key words: land acquisition; land grab; global governance; stakeholder theory; land use policy; inclusive model. 


\section{Introduction}

\subsection{Large-scale agricultural land acquisitions}

Following the food and fuel price spikes in 2007-2008, a global interest in farmlands has arisen. As a result, transnational land acquisitions have gained the attention of governments, international development institutions, media, and non-governmental organisations in recent years. Aspirations for capital export, demands by food importing nations to secure reliable supplies of food, an increasing desire for alternative sources of energy, and land speculation are among the factors that contributed to the increase of agricultural production (GRAIN, 2008; Cotula et al., 2009; Anseeuw et al., 2012; Borras et al., 2012a). Furthermore, De Schutter (2011) and Azadi et al. (2013) restated the reasons behind large-scale land acquisitions as: (a) a rush towards alternative fuel energy extraction from agro-fuels for which developed countries have encouraged transnational land acquisitions, (b) increasing population and urbanisation accompanied by the collection of natural resource bases in certain countries, (c) access to freshwater (a scarce resource), (d) rising demand for raw materials from tropical countries (primarily fibre, wood, etc.), (e) the increasing need among companies in the developed world to earn certified emission reduction credits from carbon storage projects, and (f) continued speculation on the future market prices of farmland, regardless of location.

Large-scale agricultural land acquisitions have repeatedly raised 'land-grab' concerns and have resulted in the destruction of natural ecosystems and displacement of local communities (FAO, 2009; Deininger et al., 2011; Cotula, 2011; Azadi et al., 2013). Although the contemporary views on large-scale agricultural land acquisitions are contested, many of the arguments revolve around the disputed and evolving concept of 'land grabbing'. Many have 
argued that 'land grabs' target large-scale acquisition of land in Africa, Central America, and South and East Asia (Cotula et al., 2009; Desalegn, 2011; Wilkinson et al., 2012). Others argue that the geographic scope of land grabbing is not only confined to the stated regions but also extends to such areas as the previous Union of Soviet Socialist Republics (USSR), Eastern Europe, the Middle East, Melanesia, Australia, and New Zealand (Visser and Spoor, 2011; Anseeuw et al., 2012). According to Amanor (2012), the acquisition of land extends beyond the phenomenon of global 'land grabbing' to the consolidation of power over the trans-regional value chain in particular and a component of the global 'mission' to control food and bio-fuel supply chains. Others (e.g., Harvey, 2003) have conceptualised transnational land acquisitions within the widely evolving global capitalist development framework and the distinct relationships among political economies working towards the confrontation of converging global crises in food, energy, financial capital, and climate change (Hall, 2011; White et al., 2012). Furthermore, land acquisition is considered a component of the combined outcome of globalisation, the international upsurge in foreign direct investment (FDI), and the liberalisation of land markets (Zoomers, 2010).

Land acquisitions are recommended to occur via inclusive deals that will result in a 'winwin' outcome (Azadi et al., 2013). Answering key operational questions in this process is important, i.e., Who are the players in the deal? What are their interests? How influential are the dealers involved? Without at least modest answers to such questions, merely advocating 'winwin' land deals may not result in an actual 'win-win' situation. Land grabbing also highlighted as 'control grabbing', which presages a grasping ability to control land and the accompanying basic resources to reap benefit from holding such resources (Peluso and Lund, 2011; Borras et al., 2012b). This outcome is one of the manifestations of control grabbing, implying seizure of large 
tracts of agriculturally sound land, land grab, water grab/seizure of water (re)sources (Ganho 2011; Kay and Franco 2012) and green grabs/seizure of resources for the purpose of the natural environment (Fairhead et al., 2012). Understanding the groups of stakeholders and to what extent their interests and power influence the deal will aid in formulating inclusive and win-win land deals both in de jure and de facto contexts. Lessees who acquire land usually enter into land contracts to address their strategic business interests and deal strategically, whereas actors on the side of the lessor (i.e., local government, local communities, and households) may not have such strategic intent and power. Consequently, the need exist to integrate the "power" and "interest" of the dealers in acquisition of agricultural land.

This paper first reviews the contested and evolving explanations offered for 'land acquisition' and methodologies for global land acquisition, land deals, or land grabs. Second, this work proposes the adaptation of strategic management theories, particularly the stakeholder theory of strategic management, to devise tools that are essential for responsible global governance of transnational land acquisition. This proposal attempts to develop two inclusive conceptual land deal frameworks, i.e., "land deal power-interest clustering (LD-PIC)" and "legitimacy-interest-power (LIP)". In addition, this approach proposes the creation and advancement of tripartite modelling of transnational land based on the power and legitimacy of the actors and the urgency of the needs that each actor strives to fulfil. Finally, this paper suggests issues for further review and data-based investigation. In short, this work attempts to contribute to the ongoing debates on how to ensure that global agricultural land acquisition is a more ethical and responsible investment and how to establish the power of local governance and local communities within the global land deal framework. Throughout this paper, the word "actor" is used interchangeably with "stakeholder". 


\subsection{Land grabbing: Contested and "work-in-progress" definitions}

According to a large body of literature, there is a propensity for referring to transnational land acquisitions as 'land-grabbing' without setting a comprehensive definition for this term. What is 'land grabbing?' The contested yet most commonly applied definition of land grabbing is large-scale farm land acquisition for agricultural production by non-local or foreign investors, whether through lease or purchase arrangements (GRAIN, 2008; Cotula et al., 2009; Mitta, 2009). According to Borras and Franco (2010), the term 'land grabbing' was preferably stated as 'transnational commercial land transactions' because the concept includes both domestic and transnational deals, underscoring the commercialisation feature of transactions irrespective of the size and markets for production outputs. In contrast, Graham et al. (2011) described 'land grabbing' as controlling and/or possessing land for commercial or industrial agricultural production that is not proportionate in size compared with the mean landholding in a given area, country, or region. According to Hall (2011), the phrase 'land grabbing' is activist terminology that conceals larger legitimate or structural differences and the broad impacts of commercial land transactions among beneficiaries, elites, government officers, partners of different powers, and various intermediaries. FAO-funded studies on land grabs in Latin America and the Caribbean arguably stated the definition of land grabbing. Accordingly, land acquisitions are considered as land grabs if three conditions exist in the deals: (a) the size of the deal is sufficiently large with a commonly accepted threshold of one thousand hectares per deal; (b) the need exists for direct participation of foreign governments/companies, and (c) investment on the newly acquired land is expected to have a negative impact on the food security status of the host country (Borras et al., 2012a, b). 
The majority of the literature labels and characterises transnational land acquisition as 'land grabbing'. The characterisation of 'land grabbing' is also notably (food) crisis-centred and farmland-centred as well as heavily centred on emerging players of global regimes (i.e., China, India, South Korea, and the Gulf states) and excessively centred on land acquisitions in Africa. For instance, in the case of Latin America and the Caribbean region, initiatives for food security, ventures for energy security, emerging strategies for mitigating climate change, and promising trajectories for global capital mobilisation are considered as the four key mechanisms of land acquisition. Land acquisition in Latin America and the Caribbean is characterised by its intraregional nature, i.e., many of the companies that acquired land are Latin-based and are allied with central state and international capital sources (Borras et al., 2012b). Consequently, it is important to proceed broadly from the (food)-crisis-centred definition of land grabbing, but it is also important not to define it too broadly. This statement leads us to address the distinct features of contemporary transnational land acquisition.

According to Mehta et al. (2012), water is both the target and driver of large-scale land acquisition because its hydraulic complexity poses a challenge in describing the entire process of water grabbing and its associated impacts on the environment and different social groups. This group defined water grabbing as 'a situation where powerful actors are able to take control of, or reallocate to their own benefits, water resources already used by local communities or feeding aquatic ecosystems on which their livelihoods are based' (Mehta et al., 2012: 197). However, it is quite difficult to determine the effects of water re-allocations, particularly due to inter-annual variability and surface water-ground water interactions. The absence of meaningful institutional linkages between water and land management has eased 'encroachment' of the two resources. The existing ambiguous processes of global land and water governance have 
intensified local-level complexities and uncertainties whereby the powerful actors in deals can maximise their interests through such complexities and uncertainties to the extent of expelling poor and marginalised people (Franco et al., 2013).

The size or scale of land acquired is one of the points of controversy in conceptualising and reframing 'land grabbing'. Deininger et al. (2011), Oxfam International (2011), and Anseeuw et al. (2012) couched this scale as 'large-scale land acquisition', implying deals greater than 1000 hectares. However, in the work of Borras et al. (2012b), land grabbing involves largescale land deals in two broadly interlinked but distinct dimensions of the size of land transacted and/or the amount of capital entailed. In addition to the size of land in deals, the amount of capital involved is considered in (re)defining land grabbing, a definition that is labelled as 'land measurement-oriented accounting' of farm land acquisition. For example, the figures stated are 80 million hectares in Anseeuw et al. (2012), 227 million hectares in Oxfam International (2011), and 45 million hectares in Deininger et al. (2011). None of these entities have stated a comprehensive threshold of capital that could be used to define land grabbing.

To summarise, transnational land acquisition has passed through an evolving definition and conceptualisation in the literature. Many authors preferred that these phenomena were referred to as 'land grabbing', a much debatable notion per se, whereas others considered this expression to be 'activist' terminology. Few works in the literature have set preconditions or criteria for labelling transnational land acquisition as 'land grabbing'. Certain of the criteria considered are the size of the land in the deal, the level of participation of foreign actors, and the size of capital investment, although a threshold for the "size" of capital has not been stated. The concept is further extended to include other resources (i.e., water) and hence is known as 'water 
and land grabbing'. The redefinition and (re) conceptualisation of these terms are pursued in the concept of acquiring land on transnational basis.

\section{Method and Theory}

\subsection{Methodologies for understanding global land deals}

'Land grabbing' is a hot socio-political issue throughout the world and 'getting the facts right' is crucially important. To do so, it is highly important to devise effective methodologies. Although several global efforts have been carried out to aggregate data on land deals and characterise these transactions, all have struggled with methodology (Edelman, 2013; Oya, 2013a, b; Thaler, 2013; Rulli \& D'Odorico, 2013a,b; Scoones et al., 2013a). The literature has identified immense uncertainty with respect to what is counted and questioned the methods used to aggregate 'land grabs', and hence, the need exists for development of the second phase of land deal/'land grab' research by abandoning the aim of solely deriving aggregate amounts of land deals (Rulli \& D'Odorico 2013a,b; Scoones et al., 2013a).

In their discussion on the 'politics of evidence', Scoones et al. (2013a, b) argued for a second phase of land grab research that is free from imprecise calculations and addresses important questions, i.e., what is actually occurring on the ground, who are the losers and winners, and why. Research that can extend beyond the fixation on 'killer facts' (i.e., those unproven grab numbers) and can provide statements accompanied with traceable datasets is sorely needed (Scoones et al., 2013b). In addition to the type and frequency of data collection, the question of 'what type of evidence is appropriate?' is one of the long-running methodological points of debate in the global land deal discourse (Scoones et al., 2013a), and researchers must 
think beyond qualitative versus quantitative debate. Although mixed methods/approaches are duly acknowledged, general rethinking of the form, reliability, medium for collection, and portrayal of evidence is required. Researchers must share their data in a transparent manner, become accountable for their findings, reach out to different audiences, and facilitate dialogue and debate among concerned parties (Edelman et al., 2013; Scoones et al., 2013).

\subsection{Extending the Stakeholder Theory to land use}

Extensive review of the scientific literature is carried out both in the areas of transnational farm land acquisition and the Stakeholder Theory of Management (Freeman, 1984). The parties involved in both the substantial and procedural matters of transnational land deals are explored and categorised by extending the stakeholder theory of management to land use. Conceptual limitations of the usual land deal framework are identified, and points of improvement are solicited such that the customary binary 'win-win' land deal framework can be rejuvenated as a multifaceted 'inclusive' land deal framework. Stakeholder theory attempts to address morals and values in the operation of strategically driven investment ventures and was initially described in Freeman's (1984) work of 'Strategic Management: A Stakeholder Approach', which was followed by a number of publications in academic, research, and governance areas (Donaldson et al., 1995; Friedman and Miles, 2002; Jonker and Foster, 2002). The stakeholder theory was extended from an intra-organisational and stockholder (i.e., shareholder) framework to a framework of participatory planning and decision-making framework in other areas, i.e., corporate social responsibility (Clarkson, 1995; Hillman, 2001), ethics (Agle et al., 1999), information communication technology (ICT) (Pouloudi, 1999), environmental management (Jonker and Foster, 2002), academics and education sector management (McDermott and Chan 
1996; Miles, 2011; 2012), public policy (Snider et al., 2003), management of construction projects (Bourne and Walker, 2005), health (Lim et al., 2005), and public works procurement ( Austen et al., 2006). Continuing the thread to the contemporary challenge of global governance of land grabbing (Borras et al., 2013), we introduce the application of the stakeholder theory in explaining the diverse stakeholders in a land deal.

In line with the power that transnational companies wield together with the powers of other stakeholders, these companies (as in any type of business ventures) apply their own strategic techniques in pursuing their own business interests and affiliation. One of the most important requirements that should be considered during the business strategy-making process for companies is their ability to identify intra-institutional success factors. By the same token, in the age of global land grabbing, companies are involved in the transnational acquisition of farmlands, but land has a number of competing functions. The influence of other stakeholders, (i.e., government, local communities, international community, elites and researchers, political parties, etc.) is quite noticeable. In line with Mitchell et al. (1997), it is essential to cultivate a comprehensive mindset if a win-win transnational land deal is to be established. Inclusive understanding of the key actors and players and successively taking into account their interests and power bases aids in maintaining the efficacy of handling and managing the competitive interests of land use among competing stakeholders with different abilities to influence land deals.

Each party in a land deal has a unique set of stakeholder(s) with which to work and likely a unique or similar set of reactions to a particular set of land use propositions. It is a tradition of land-seeking transnational companies to pay due attention to such stakeholders' interests (Mason et al., 2007). Companies use their own tactical measures to influence land deals and maintain 
long-term viability of earnings while strengthening their power through their investment operations. According to McMichael (2013) and Araghi (2003), transnational acquisition of land is considered as "Security Mercantilism in International Relations" through which current food regime power restructuring is manifested within its global economic, political, and social coordinates.

\section{Results and Discussion}

\subsection{The land deal power-interest clustering (LD-PIC) framework}

Understanding competing interpretations and political views without a comprehensive land deal framework to incorporate the diversified interests of land use and powers of stakeholders is a major challenge (Borras et al., 2013; Margulis et al., 2013). The indispensable role of strategic management tools in mapping possible power-interest combinations is crucial to the prevailing multi-polar governance challenges of transnational land grabbing. Consequently, we described the relevance of the 'power-interest grid', a conceptual map that disaggregates the stakeholders, their vested power, and the magnitude of interests they are likely to reflect (James et al., 1986; Freeman, 1994; Agle et al., 1999; Ackermann and Eden, 2003) (Figure 1). 


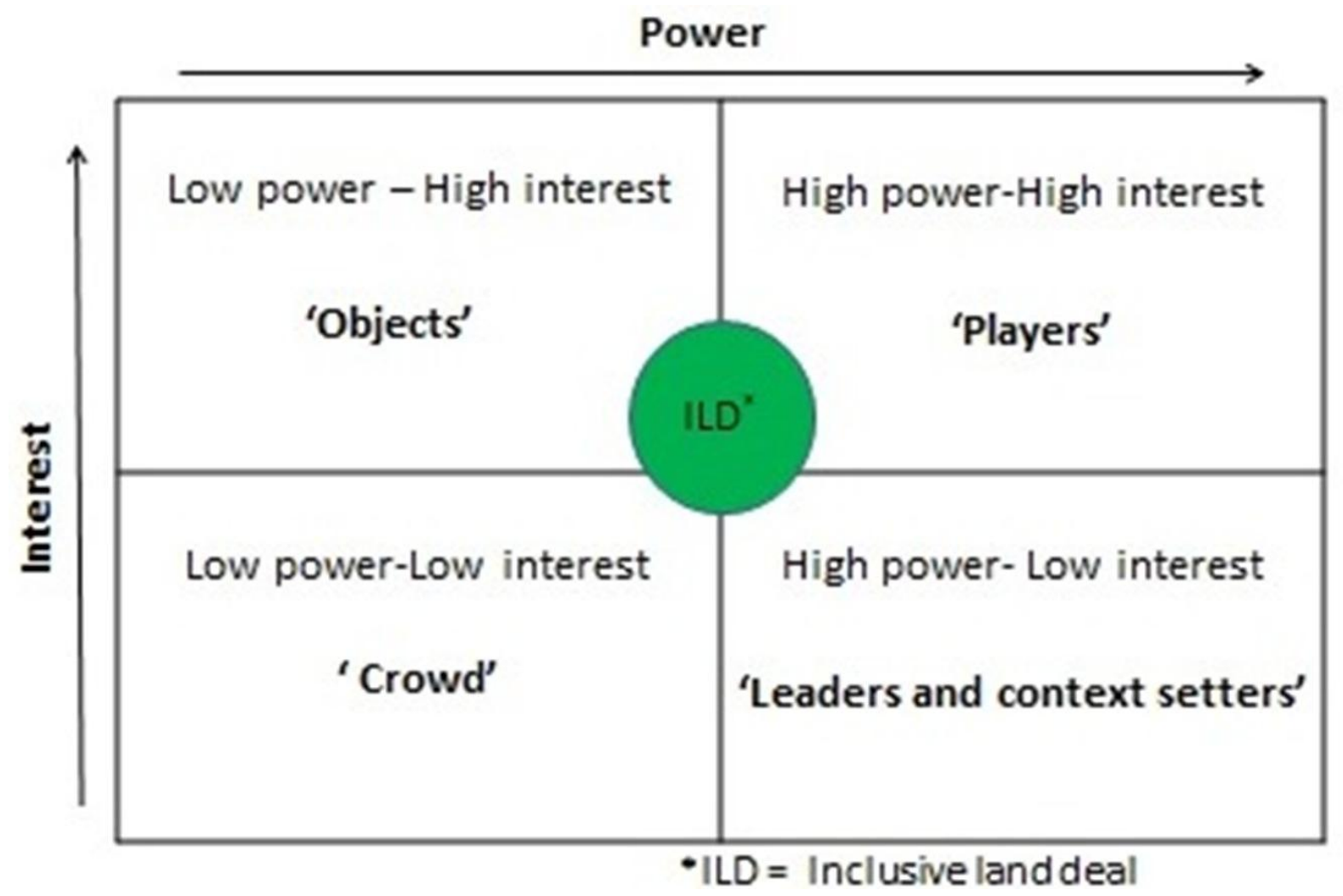

Fig. 1. Land deal power-interest clustering (LD-PIC) framework

(Adapted from the strategic management literature by James et al., 1986; Freeman, 1994;

Mitchell et al., 1997; Ackermann and Eden, 2003)

This tool is supportive in narrowing down a large number of conceivable stakeholders to a manageable array with which to set the foundation for a win-win land deal. Focusing on the key actors or stakeholders with substantive procedural matters for win-win land deals is analogous to effective stakeholder management strategic deliverables. The LD-PIC is useful in classifying land deal stakeholders that take on central actor roles by supporting or sabotaging the intent of win-win land deals. For example, in the strategic management literature, Rowley (1997) and (Bronn, 2003) constructed aggregations of stakeholders into 'actors' or 'parties' (i.e., those context setters, players, and 'stakeholders' who are neither context setters nor players but other 
groups who have a stake in the deal or process). The LD-PIC framework can be described as one of the possible extensions of the Stakeholder Theory and attempts to explain and forecast multiagent or organisational functions with respect to stakeholder influences in the contemporary era of global 'land grabbing' or transnational land acquisition. Although confusion often occurs relative to the theory itself, adaptation of the stated theory to real-world scenarios is important in developing platforms for issues that contain many interests and stakeholders with diverse interests and disparities of power (Miles, 2011).

An understanding the position and power of different stakeholders in land deals plays a crucial role in ensuring the accountability of companies that acquire land globally (Cotula, 2011). Power is the potential for obtaining a desired result in relationships in which there are competing or opposite interests (Winkler, 2009). Although a party in a deal may hold power at a certain time, this does not necessarily mean that it holds that power indefinitely over time and space. This statement does not imply that there might not be changes in power throughout a given relationship (Elkin, 2007). Power also can be conceptualised as the ability of a stakeholder to exert influence on its survival (or interests) based on the ownership of and/or access to relevant resources (Winkler, 2009). However, interest is the aspiration or a feeling of wanting to be considered or wanting to take part in a valuable process (in this case, land and its accompanying resources), although selected works in the literature have labelled this as 'urgency' (Agle et al., 1999). Furthermore, amalgamating the power and interest of stakeholders with their degrees of legitimacy is important in analyzing the stakeholders in a land deal in a more comprehensive manner. Legitimacy is a generalised assumption or a perception that the actions of a party or stakeholder are appropriate, desirable, or proper within a given socially constructed system of beliefs, definitions, norms, and values. Legitimacy determines whether a 
land use claimant or stakeholder is proper, desirable, or suitable to the social beliefs, norms, and values used in the given context. It is also argued that the legitimacy of a stakeholder is granted by a given society (Agle et al., 1999).

\subsubsection{Low power/high interest cluster: The 'Objects'}

Parties or stakeholders with comparably low power but high interest can be categorised as 'Objects'. These entities are positioned with high interest, which could be positive or negative depending on their reason for existence (i.e., mission) and vision. In the conventional business world, mapping of all stakeholders is a strategic business prerequisite. Accordingly, this process selects appropriate approaches to meet unilateral or bilateral interests. To this end, the 'Objects' cluster constitutes the 'keep them informed' group, a group that has a high interest in the actions of the companies but holds relatively low power and requires much communication work from the 'players' group (James et al., 1986; Mitchell et al., 1997). Due to their low power, these groups play a passive role in a land deal, and hence we refer to them as the 'Objects', although they are referred to as 'Subjects' in much of the strategic management literature (ibid). However, companies are not complacent, and the aggregated effect of many disgruntled stakeholders can grow. In a similar analogy, to incorporate or consider such parties in transnational land acquisitions and work for an Inclusive Land Deal (ILD) arrangement, it is crucial to encourage coalitions to increase the power of the members of this group and engage them in the deal (Bernal, 2011).

A number of land deal cases have resulted in highly displeased stakeholders, and many of these situations are characterised by bi-lateral land deals that neglected a number of pertinent actors who were actually 'powerless'. For instance, the acquisition of land by Dominion Farms 
(a Texas-based company) in Western Kenya resulted in conflicting land rights and land use, and Dominion farms was subjected to many critical investigations and reviews (FIAN International, 2010; Galaty, 2012). In 2003, an agreement was made between Dominion and the county councils 'to develop' 17,000 hectares of swampland adjacent to Lake Victoria for the duration of 25 years with a possible extension period. During the deal, local community members who used the land for pasture, fishing, and crop production (especially during the dry season) were not considered and were treated only as 'subjects' in the deal and received communication later in the process through local religious channels. The company followed legal procedures and negotiated with trustees, although there was severe resistance against the agreement from local community groups (Ochieng, 2011). Despite the fact that many blame the company for 'grabbing' the land, which has livelihood importance for the local community, others named the government as a responsible 'player' in the deal. A number of land use conflicts and fears resulted from this non-inclusive land deal, and the company has invested significant resources to settle local grievances, disputes, and court cases. Furthermore, an unusually long ranging conflict has occurred between local country councils on the subject of sharing the amount of land between the residents and the company (Anseeuw et al., 2012). However, local community groups were supported by different stakeholders and became relatively powerful in pursuing cases against the relevant institutions for settlement. If the company had passed through the appropriate steps of identification and inclusion of all relevant stakeholders together with their varied interests and power from the beginning of the deal, all of those conflicts might not have occurred. Despite the fact that the Texas-based company faced all these challenges in Kenya, it expanded its operation into the Taraba state of Nigeria and Liberia, where it succeeded in 
acquiring 30,000 hectares and 17,000 hectares of land, respectively, with state backing and 'context setting' (GRAIN, 2012).

\subsubsection{High power/high interest cluster: The 'Players'}

Stakeholders or parties with high power and high interest are categorised as 'players'. These parties are the key actors in land deals who receive much attention from the 'Leaders and context setters' group. In many land deals, due focus is given to this group, followed by the 'leader and context setters' cluster. The literature states that 'players' in a deal may deliberately act via sabotage to fulfil their strategic aspirations, although their success or failure is meaningfully affected by the behaviour, position, and strategic interest of the 'leaders and context setters' (Donaldson et al., 1995). Using their high power and high interest, the genuine role of 'players' in transnational land acquisitions is to influence dealers to adhere to the recommended guidelines of corporate social responsibility and integration of environmental and social governance standards. Although the state is usually invoked as a key player in land acquisition, Wolford and Borras (2013) argued that states never function with the same voice, and hence unbundling of the state is argued as helpful in viewing government and governance as people, processes, and relationships.

Among those real-world cases, in 2008, the Swiss-based energy company Addax Bioenergy obtained 14,300 hectares of land in the form of long-term lease agreements for 50 years in central Sierra Leone. An agreement was made to produce bioenergy (i.e., ethanol) for export to Europe and generation of electric power for the local energy market (for energy users in Sierra Leone). To meet its business objective, the company reached an agreement with a number of powerful and interested 'players' in acquiring the African land. The African 
Development Bank (AfDB), the Netherlands Development Finance Company (FMO), the UKbased emerging Africa Infrastructure Fund (EAIF), the German Development Finance Institution (DEG), the Belgian Development Bank (BIO), the South African Industrial Development Corporation (IDC), and Cordiant managed the ICF Debt Pool to provide the company a debt financing agreement of $€ 142$ million. Furthermore, Swedfund (the Swedish Development Fund) and the Netherlands Development Finance Company (FMO) joined the company as shareholders, elevating the overall size of the investment to an estimated $€ 267$ million (Addax Bioenergy, 2012). However, the other Swiss-based investigation group of Brot für Alle carried out a basic analysis of Addax's operations and exposed that the company would reap a return of US\$53 million per year, which is close to $98 \%$ of the value added by the company's operations. Those stakeholders who hold high power and high interest in a deal do have high bargaining power, which leads them consciously or unconsciously into a suppressive and exploitative transaction. For example, relative to the Addax company case, its low-paid employees (approximately 2000) would receive only $2 \%$ of the value-added, and the owners of the land leased by Addax would receive approximately $0.2 \%$ of the added value. Thus, the company provides less than US $\$ 1$ per month for each person affected by its operations or projects, according to a similar recent report by GRAIN (2012). Furthermore, the Government of Sierra Leone acted as the prominent supporter of the community resettlement plan developed by Addax for expansion of its sugar cane plantations. 


\subsubsection{High power/low interest cluster: The 'Leaders and context setters'}

The composition of stakeholders that can influence the overall context of a deal could be contextualised as the 'leaders and context setters' cluster. Parties or stakeholders in this group must be assured with a 'keep them satisfied' tactical endeavour for the 'players' to fulfil their desired investment interests (Jawahar and McLaughlin, 2001; Gardner et al., 1986). A number of real-world cases can be classified into this group and are described as follows.

The World Bank: The World Bank's Multilateral Investment Guarantee Agency supplied a company, i.e., Chayton Capital, with US\$50 million for political risk insurance in farm holdings in Botswana and Zambia (GRAIN, 2012). The World Bank advocates 'nine billion reasons' to invest in agriculture. Furthermore, in 2012, the International Finance Corporation (IFC), which is the World Bank's private sector component, invested US $\$ 4.2$ billion in largeand small-scale agribusiness and forestry enterprises engaged in growing food and fibre, which were expected to employ workers and assist in feeding the world (World Bank Group on Land and Food Security, 2012). However, although the World Bank is blamed for its support for 'land grabbers' and for dealing with the national governments of developing countries (as 'context setters'), it has rejected this blame. For instance, the World Bank has rejected Oxfam's call to suspend its involvement in large-scale transnational land acquisition in developing countries, particularly that of Africa (World Bank, 2012): 'A moratorium focused on the Bank Group targets precisely those stakeholders doing the most to improve practices - progressive governments, investors, and us. Taking such a step would do nothing to help reduce the instances of abusive practices and would likely deter responsible investors willing to apply our high standards,' The World Bank has officially replied (p. 4). Payne and Murrin's UK company, which began operating their African Agricultural Land Fund in 2007, acquired 30,000 ha of land 
in Mozambique and other African countries with support from the Toronto Dominion Bank of Canada and the ISA endowment fund of Vanderbilt University (GRAIN, 2012).

The European Union: The European Union supports 'pro-land deal' policies. For instance, the EU's 'Everything but Arms (EBA) trade policy' is an agreement stating that imports to the EU from the least developed countries are freed from any restriction or duty, except for ammunitions and arms (European Commission, 2000). This component of the EU's trade policy was formulated with the intention of supporting developing countries; however, this policy could also indirectly encourage 'land grabbing'. Companies in Europe and other countries will go to developing states such as Ethiopia and acquire cheap land, cheap investments, and trade licenses and will ultimately benefit from the EU's 'Everything but Arms (EBA)' import policy. It is a public fact that many companies from the EU member countries, e.g., Dutch and German companies, have acquired large amounts of land in Ethiopia by dismantling local communities who have lived on 'their' land for hundreds of years. In contrast, the governments of developing countries argue that local communities are dislocated for the good reason of attracting foreign direct investment (FDI) and not 'land grabbing'. This policy encourages agricultural land acquisition by European, Arab, Chinese, and Indian profit-oriented companies to rush for largescale agricultural lands in developing countries in the global South (Transnational Institute, 2012).

The case of the EU's international investment policy: In bilateral investment treaties, the EU's investment policy constitutes such terms as 'stabilisation', which are intended to immunise European companies from any changes made to the laws of the host countries, i.e., developing countries (European Commission, 2006). Accordingly, European companies are encouraged and even have fundamental power to influence the state laws of host countries. 
The case of the EU's renewable energy directive: The EU has declared that by the year 2020, the share of renewable energy consumption in the EU will be increased; one example is biofuel (European Commission, 2012). With policies of such types, we argue that the EU and related institutions in other intergovernmental and regional organisations are among those actors or "context setters" who intentionally and/or unintentionally set favourable contexts for companies and other actors to acquire cheap land in developing countries.

\subsubsection{Low power/low interest cluster: The 'Crowd'}

The 'crowd' cluster constitutes stakeholders with low interest in a deal combined with low power to influence the deal. The 'crowd' is a group that constitutes those stakeholders who have little impact on the process of land acquisition. For the 'crowd', substantive and procedural factors might apply that result in their possession of low power and interest in the land. For instance, factors such as availability of smallholder local development schemes, direct or indirect control of local administrative institutions, land tenure arrangements, the location pattern of investments and villages, informal land transactions, etc. are among the factors that could result in certain local people with low power and interest at a given time (McCarthy, 2010). The cluster constitutes the 'minimal effort' strategic wing of companies in designing their competitive business schemes, thus requiring minimal investment to win the interest of these groups (Mitchell et al., 1997; Bernal, 2011). These actors can be treated as potential rather than actual stakeholders in a land deal, and it may be necessary to raise their interest in the case of long-run land deals or acquisitions over a longer period of time. The 'crowd' is the group or cluster of stakeholders who, at this stage, do not pose significant land-deal-related issues that require 
further discussions compared with the other groups in the land deal power-interest clustering (LD-PIC) framework.

Most non-governmental organisations, community-based organisations, certain of the local administrative structures, members of district or provincial legislatures, and members of parliament in the recipient communities of land deals are reasonably categorised in this group. Others, particularly those with high power, receive much attention in many of the contemporary land deals that occur in many developing countries. The strategy used to build capacity, generate interest, raise awareness, and communicate the ground-level perceived effects of investments plays a vital role in ensuring that this group is reactively responsive to non-inclusive land deals (UNCHS, 2001). However, the low level of interest and lower power of this group might change rapidly due to institutional, policy, governance, or demographic changes over time.

\subsection{Legitimacy, interest, and power of the land deal framework}

Disaggregation of the concept of 'stakeholder' (an overused term in the transnational land deal literature) into a meaningful classification is an important step. A good point of departure in this case is the power, legitimacy, and urgency or salience model (Mitchell et al., 1997). This model clusters stakeholders according to business corporate performance and managerial values from which the legitimacy, interest, and power (LIP) modelling of parties in land deals can be

reframed (Figure 2). The term is further extended into subcategories of potential actors in a land deal described as latent, discretionary, dependent, exigent, dominant, dangerous, and definitive. 


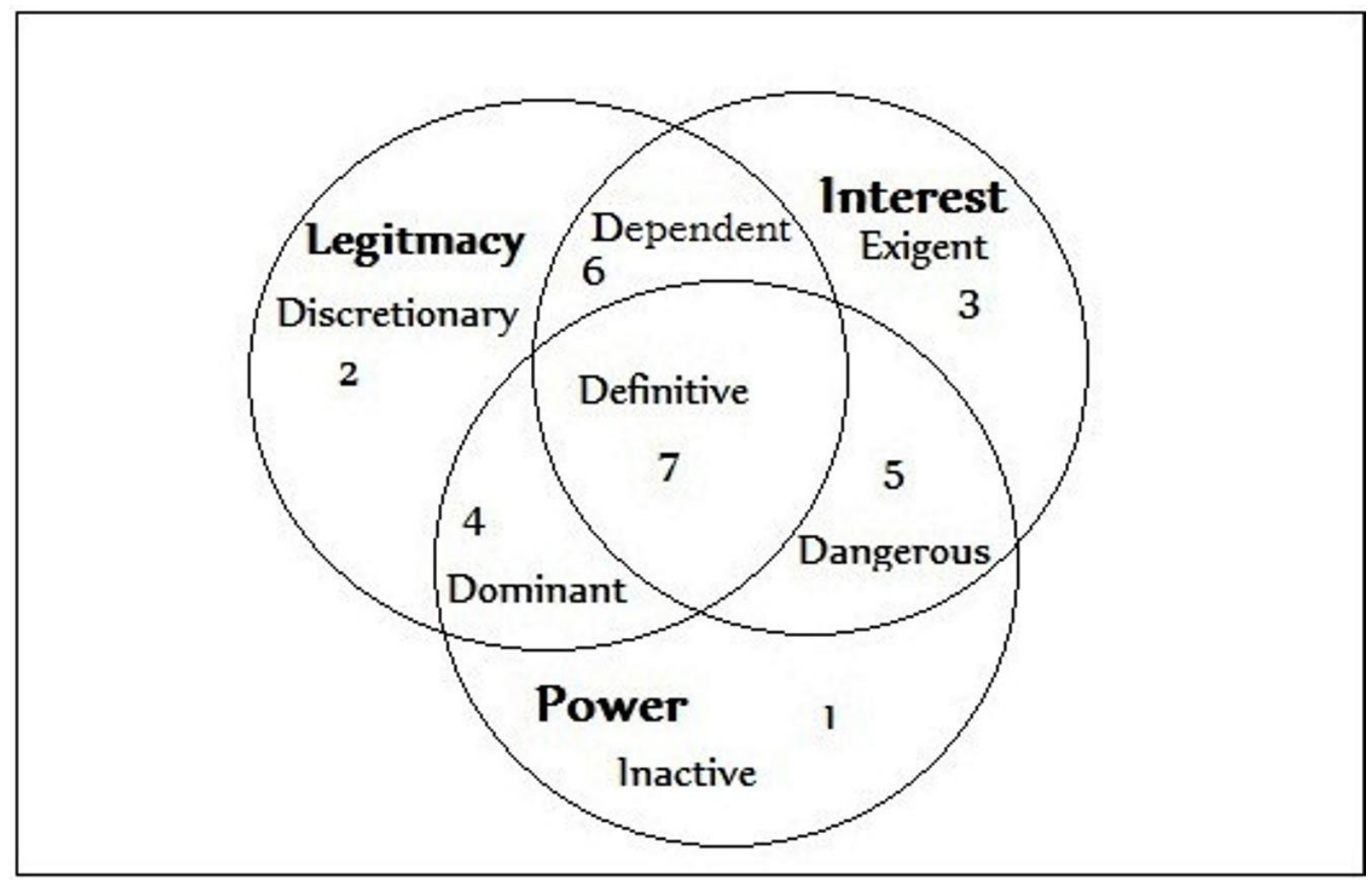

Fig. 2. Legitimacy-interest-power (LIP) land deal framework

(Adapted from Mitchell et al, 1997)

Inactive stakeholders hold the power to enforce their interests over others, yet they lack urgency and legitimacy, and hence, their power to influence deals and acquisitions remains dormant. Discretionary stakeholders have the legitimacy to present claims in a deal, but they are not interested in doing so primarily because they likely lack power or other contextual explanations. The exigent sub-group constitutes stakeholders with urgent claims, yet they have neither legitimacy nor power to enforce them in a deal. Dominant stakeholders are those with legitimate claims and power to influence a deal as well as resource entitlement that allow them to wield a stronger influence in a deal. Parties with power and interest but no legitimacy are strategically known as 'dangerous' stakeholders because they may opt for coercion or violence if they are not appropriately engaged in a deal or dissatisfied with the consequences of the deal. Dependent 
stakeholders do not have power, although they have interest and hold legitimate claims in a deal. If the power of this group is improved through different capacity-building schemes, they can easily negotiate with other stakeholders and influence a deal or resource acquisition. Finally, definitive stakeholders hold the power and legitimacy to push their interests in a deal. The important questions are states as follows: Who are those three broader groups and the seven distinct clusters of stakeholders in a given land deal made in a certain country, region, or location? Who lacks legitimacy, interest, or power in the deal? What should be done and for whom such that land deals and acquisitions will end not only in a win-win outcome but also inclusive decisions?

Parties or stakeholders that exhibit only one of the three characteristics (stakeholders numbered 1, 2, and 3 in Figure 2) might be re-categorised as latent stakeholders in such subclassifications as inactive, discretionary or exigent/demanding with analogies to the upper-level classification. Stakeholders who display two of the three characteristics (those numbered 4, 5, and 6) are categorically expectant stakeholders known as dominant, 'dangerous', or dependent, respectively. Those parties or stakeholders who are interested in the subject(s) in a deal, have the power to influence the deal, and hold legitimacy in the deal and its related matters are definitive stakeholders. A key issue in many of these discourses is the maintenance of an appropriate triangulated balance among the tripartite elements of legitimacy, interest, and power.

An inclusive land deal (ILD) is envisioned to further address the economic, ethical, legal, and discretionary responsibilities or matters embedded in the different stakeholder groups and subgroups explained thus far. Economic inclusiveness: The 'profitability of the deals' or businesses following the land acquisition should seek to generate acceptable benefit or return for the acquired land. Ethical inclusiveness: Responsibility exists in a land deal to cooperate in policies 
that are fair, just, and right, and refrain from harm, i.e., the duty to choose wisely among several alternative uses of land and/or accompanied resources. Legal inclusiveness: This category includes 'the legal contexts of the deals', which involves obeying the pertinent laws that codify right and wrong. Discretional inclusiveness: Companies and others who acquire land are expected to act as good (corporate) bodies by deploying their resources for the improvement of other stakeholders' well-being and quality of life, e.g., devoting resources to improving the livelihood of local communities.

\subsection{From 'win-win' to an inclusive land deal framework}

The governance of transnational land acquisition becomes a challenge in a changing international agricultural context with competing political perspectives and strategies, making the existing governance landscape more complicated (Borras et al., 2013). Land acquisitions can pose major threats to the livelihood of family farming and the rural poor that are ultimately disadvantageous to countries that supply land and therefore cast criticism on such commercial land deals (Bues, 2011). However, certain factions believe that such investments should not be generally condemned. Many investors who obtain land in certain developing countries face unknown performance in sustainable land use and forest resources, and most do not work with local labour and technology, and ship their production back to their home countries (Desalegn, 2011; Dereje et al., 2013). From this view, such investments might endanger the amount of available food and increase food insecurity among the recipient communities. In particular, the large number of subsistence poor farmers who depend on land to feed their families will be affected by land scarcity and rising land prices (Azadi et al., 2013). Limited empirical studies have shown the 
effects of large-scale land acquisitions on family farming and small-scale food production (Gobena, 2010; IFAD, 2011).

Small-scale farmers or family farmers produce $80 \%$ of the food consumed in developing countries, but their agricultural operations are threatened and under continued upheaval due to land tenure, land governance, and transnational land acquisition (ILC, 2014). Family farming must be considered as one of the cornerstones of sustainable rural development and should be conceived of as an integral component of the global food value chain. Resolving the predicaments of family farming and harmonising this factor with large-scale land transactions is essential.

A proper identification and inclusion model for the relevant stakeholders in land deals is lacking, which further contributes to governance complexities and non-inclusive and selective participation of parties in deals that end with long-term transfer of farmlands. Win-win land deals can be mostly sustainable (green) deals and are hence recommended (Azadi et al., 2013); the conventional context of win-win deals implies that these agreements are made between two dealers or two stakeholders, but the main issue in the case of land deals goes beyond that explanation. Numerous further stakeholders exist with diverse and often conflicting interests and differentiated powers and aspire to play a role in given land deal, yet they are marginalised. However, it is not sound to develop a 'one-size-fit all' inclusive land deal (ILD) conceptual model in a contemporary land (use) market that differs in various parameters of location, land use, crop type, and socio-political and cultural contexts (GRAIN, 2008; Akram-Lodhi, 2012). Furthermore, 'land grabbing' is a 'work-in-progress' concept according to which the inclusive land deal models may involve real-world cases and tailored frameworks. Inclusive land deals can be sustainable land deals or green deals, which are not easy to construct and hence could be 
inevitably complex in practical terms. Win-win land ideas, as described in Azadi et al. (2013), are a necessary but not sufficient criterion for land deals to be characterised as sustainable or green deals. As green deals, land deals must simultaneously consider the systematic and multidirectional interactions of the biophysical environment, institutions, and stakeholders (Figure 3).

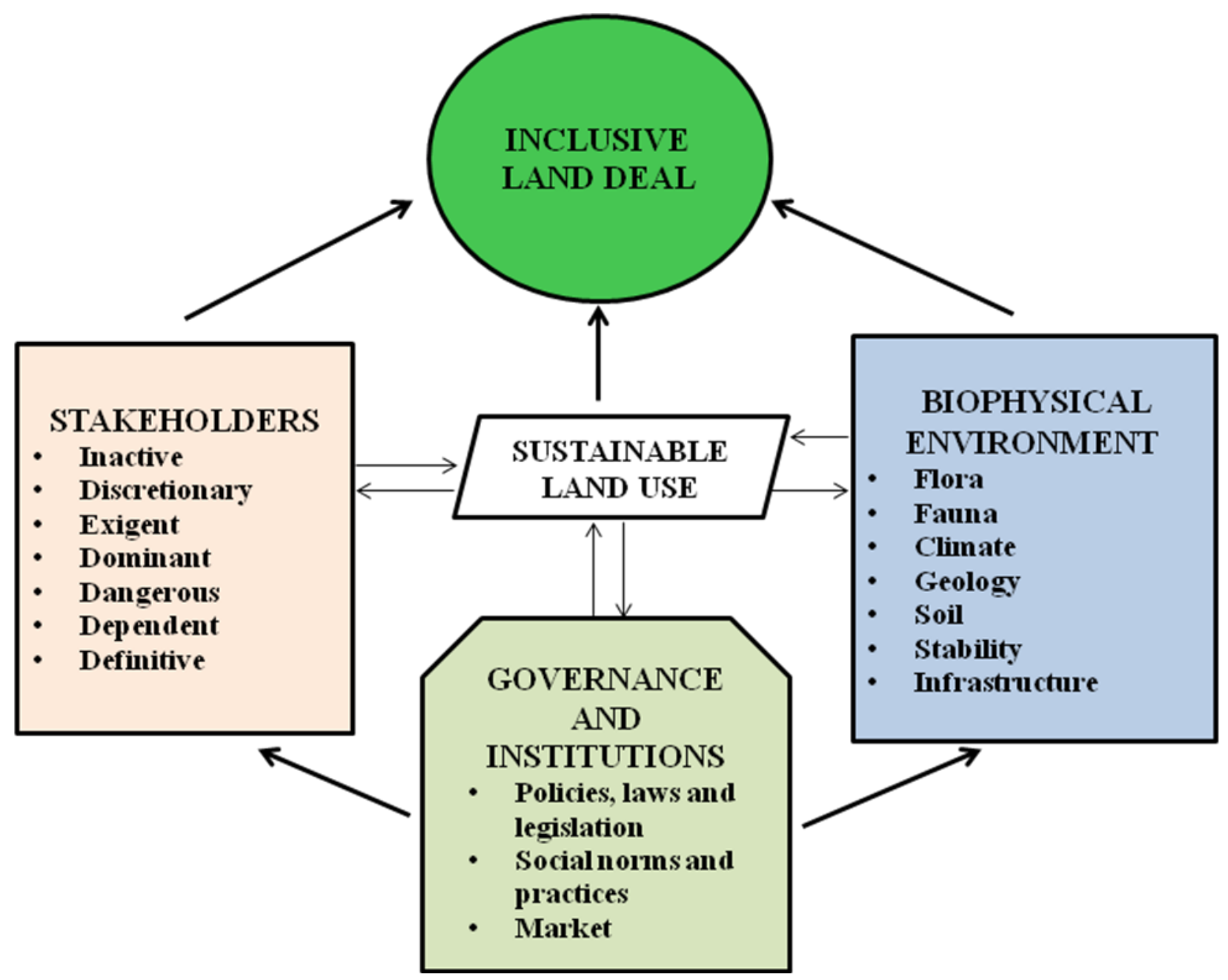

Fig. 3. Sketch of the inclusive land deal (ILD) framework 
Our proposed inclusive framework depicts an inclusive land deal as a function of three grand indices, i.e., biophysical environment, governance and institutions, and stakeholders, in which each is the focus of different areas of expertise. In short, the framework can be equated as follows:

ILD $=f($ bpe, gins, sths, Lu) +e; where

ILD: Inclusive land deal,

bpe: Biophysical environment,

gins: Governance and institutions,

sths: Stakeholders,

Lu: Land use, which is the cumulative effect of biophysical environment, institutions, and stakeholders, and

e: Effect of latent factors

Consideration of transnational land deals relative to the biological and physical environment that constitutes the flora, fauna, climatic situations, geological make-up, soil condition, infrastructure, and stability of the area, etc. are among the efforts considered in the inclusive deals. The ILD should not only protect and preserve the biophysical environment but also should be viewed from the context of power and interest in moving transnational capital for better benefit maximisation through the use of the biophysical resources of the host countries and communities. Transnational acquisition of land must be viewed from the broader context of occupying land and its accompanying resources, i.e., water for small-scale land-holding peasants 
and local households (Ganho, 2011; Kay and Franco, 2012). Excessive focus on the land per se runs the risk of overlooking the basic drivers behind transnational land acquisition, i.e., greed for power in the global food and input supply chain and harnessing control over biophysical prerequisites to further capital accumulation.

Governance and institutions are the most important variable in the ILD framework, which is clear but illusive in many of the contemporary land deals. Accountable, consensus-oriented, effective and efficient, equitable and inclusive, participatory, and responsive and transparent governance of land use and its associated resources are prerequisites for an inclusive process in transnational land deals. Assessing the adherence of transnational land deals to the principles of accountability, transparency, and responsible agricultural investment contributes to ensuring sustainable land use rather than simple focus on the exchange of land ownership or land use. Assessment of the contexts and improvement factors related to land (i.e., policies, legislations, laws, directives, and market) in such an approach could aid in facilitating good governance and transactions of land. As discussed in the previous sections, the stakeholders must be considered, and their genuine participation is a requirement for inclusive deals. Protection of vulnerable groups, i.e., local economies, social fabric, and cultures, is also a basic need. The right to food and nutritional sovereignty as well as respect for the available social norms and practices are among the components of responsible agricultural investments. Finally, synchronising the interplay among the biophysical environment, stakeholders, governance, and institutions in the context of competitive land use is essential. 


\subsection{Adapting and refining the proposed frameworks: Checklist questions}

The need exists to bridge the gap between "generalised" and "contextualised" knowledge (and information) concerning transnational land acquisition. Most of the generalised conceptualisations and sources neglect the importance of powerless and powerful (yet uninterested) stakeholders in deals surrounding land use (Amanor, 2012; Anseeuw et al., 2012). The important questions are: Who are the three broader groups and seven distinct sub-groups of stakeholders in a land deal? Who lacks legitimacy, interest, or power in the deal? What should be carried out by whom and for whom such that land deals and acquisitions will end up with not only win-win outcomes but also inclusive decisions? For land deals to become inclusive resource use agreements and to be governed in line with meaningful environmental and social governance standards, these following fundamental questions should be addressed in real-world contexts, land use types, and socioeconomic and political settings.

\section{Conclusion}

Recent works on transnational land acquisition argue towards win-win land deals or 'green deals' (Azadi et al 2013). However, a 'win-win' situation is a necessary but not sufficient condition for land deals to become inclusive or effective green deals. To obtain an inclusive land deal, the need exists to broaden the groups of stakeholders (i.e., in addition to the investor and investee) according to various but relevant parameters. By extending the evolving stakeholder theory of management to the emerging governance challenges of transnational land deals, we propose a new concept known as the land deal power-interest clustering (LD-PIC) framework. Stakeholders in a transnational land acquisition are categorised into either four or seven generic 
groups depending on the power, interest, and legitimacy with which they are vested. First, according to the LD-PIC, actors in land deals can be categorised into four groups, i.e., subjects, players, leaders-context setters, and crowd. The first group of 'subjects' are those groups of stakeholders with high interest in the land considered in a deal but with low power to influence both the process and outcome of the deal. In contrast, the second group of 'players' are those stakeholders who have high power and high interest, including the designers and real actors of deals that use the contexts set by the third group of leaders and context setters. The leaders and context setters group consists of stakeholders with low interest in the deals but comparatively high power in influencing the context of the deal. The last yet not least group of the 'crowd' are stakeholders with low power and low interest relative to land deals.

By adapting the concept of 'legitimacy' into our LD-PIC framework, we introduce the legitimacy, interest, and power (LIP) land deal framework. Accordingly, seven distinct groups of stakeholders are created from the context of transnational land acquisition, i.e., inactive, discretionary, exigent, dominant, dangerous, dependent, and definitive. Although all of these groups of stakeholders do exist, unfortunately, the land use agreements that have been made thus far have occurred between only two parties, i.e., the leaser and lessee. However, if an inclusive land deal is assumed, the interplay between the leaser and lessee and also among these seven groups of stakeholders as well as its implications for sustainable land use must be properly understood. Considering the systematic and multidirectional interactions of the biophysical environment, institutions, and stakeholders, we offer an inclusive land deal (ILD) framework. The framework portrays the inclusive land deal as a function of three grand variables: biophysical environment, governance and institutions, and stakeholders. Finally, understanding and improving the theoretical realm of the ILD framework of stakeholders is a current issue, and 
it is crucial to apply or use this framework in the further steps of assessing specific land deals, land use, crops, governance, institutional, and location cases.

\section{Acknowledgement}

The lead author is a beneficiary of a doctoral research grant from Ghent University's Special Research Fund (BOF). We thank Ghent University. Thanks also to Mekelle University, the International Foundation for Science (IFS), Ministry of Agriculture of Ethiopia, and Ethiopian Investment Authority. Furthermore, the constructive comments which were provided by two anonymous reviewers are strongly acknowledged.

\section{References}

Ackermann, F., Eden, C., 2003. Powerful and interested stakeholders matter:Their identification and management. American Academy of Management Conference, 2003-08-01, Seatle, USA.

Addax Bioenergy, 2012. Prospect of Bio-fuels in Sierra Leone | Self-Publishing at GRIN. available from http://www.grin.com/en/e-book/230290/prospect-of-bio-fuels-in-sierra-leone [accessed on 14 February 2013].

Agle, B.R., Mitchell, R.K., Sonnenfeld, J.A., 1999. Who Matters to CEOs? An investigation of stakeholder attributes and salience, corporate performance, and CEO values. Academy of Management Journal 42(5), 507-525. 
Akram-Lodhi, A.H., 2012. Contextualising land grabbing: contemporary land deals, the global subsistence crisis and the world food system. Canadian Journal of Development Studies/Revue canadienne d'études du développement 33(2).

Amanor, K.S., 2012. Global resource grabs, agribusiness concentration and the smallholder: two West African case studies. Journal of Peasant Studies 39(3-4), 731-749.

Anseeuw, W., Boche, M., Breu, T., Giger, M., Lay, J., Messerli, P., Nolte, K., 2012. Transnational Land Deals for Agriculture in the Global South Analytical Report based on the Land Matrix Database, Bern/Montpellier/Hamburg: CDE/CIRAD/GIGA. Available at: http://www.landcoalition.org/sites/default/files/publication/1254/ (Accessed 11.02. 2013)

Araghi, F., 2003. Food regimes and the production of value: Some methodological issues. Journal of Peasant Studies 30(2), pp.41-70.

Azadi, H., Houshyar, E., Zarafshani, K., Hosseininia, G., Witlox, F. , 2013. Agricultural outsourcing: A two-headed coin? Global and Planetary Change 100, 20-27.

Bernal, A.M., 2011. Power, Powerlessness and Petroleum: Indigenous Environmental Claims and the Limits of Transnational Law. New Political Science 33(2),143-167.

Borras, S.M., Franco, J.C., 2010. Towards a Broader View of the Politics of Global Land Grab : Rethinking Land Issues, Reframing Resistance, 1001 LD Amsterdam, The Netherlands

Borras, S.M., Kay, C., Gómez, S., Wilkinson, J., 2012a. Land grabbing and global capitalist accumulation: key features in Latin America. Canadian Journal of Development Studies/Revue canadienne d'études du développement, 33(4), 402-416.

Borras, S.M., Franco, J.C., Gómez, S., Kay, C., Spoor, M., 2012b. Land grabbing in Latin America and the Caribbean. J. Peasant Stud. 39(3-4), 845-872. 
Borras, S.M., Franco, J.C. \& Wang, C., 2013. The Challenge of Global Governance of Land Grabbing: Changing International Agricultural Context and Competing Political Views and Strategies. Globalizations 10(1),161-179.

Bourne, L. \& Walker, D.H.T., 2005. Visualising and mapping stakeholder influence. Management Decision 43(5), 649-660.

Bronn, S.P., 2003. A reflective stakeholder approach: Co-orientation as a basis for communication learning. Journal of Communication Management 7(4), 291-303.

Bues, B.A., 2011. Agricultural Foreign Direct Investment and Water Rights : An Institutional Analysis from Global Land Grabbing. In Global Land Grabbing. Sussex: Land Deals Politics Initiative (LDPI).

Clarkson, M.E., 1995. A stakeholder framework for analysing and evaluating corporate social performance. Academy of Management Review 20(1), 92-117.

Cotula, L., 2011. Land deals in Africa:What is in the contracts?, London WC1H ODD, UK: International Institute for Environment and Development (IIED).

Cotula, L., Vermeulen, S., Leonard, R. And Keeley, J., 2009. Land grab or development opportunity? international land deals in Africa Land grab or development opportunity?, London/Rome: FAO, IIED and IFAD.

Dereje, T., Witlox, F., Azadi, H., Mitiku, H., Nyssen, J., 2013. International land deals , local people's livelihood, and environment nexus ( How to create win-win land deals in Ethiopia ?). In Geophysical research abstracts. Veinna, Austria: General Assembly of the European Geosciences Union, p. 1. Available at: http://meetingorganizer.copernicus.org /(Accessed 12.10. 2013). 
De Schutter, O., 2011. How not to think of land-grabbing: three critiques of large-scale investments in farmland. Journal of Peasant Studies 38(2), 249-279.

Desalegn, R., 2011. Land to investors: large-scale land transfers in Ethiopia, Addis Ababa. available from http://www.landgovernance.org/ [accessed on 15 October 2012].

Donaldson, T., Preston, L.E. \& Preston, L.E.E.E., 1995. The Stakeholder Theory of the Corporation: Concepts, Evidence, and Implications. Academy of Management Review 20(1), 65-91.

Edelman, M., Oya, C. \& Jr, S.M.B., 2013. Global Land Grabs : historical processes , theoretical and methodological implications and current trajectories. Third World Quarterly.34(9), $517-1531$.

Elkin, J., 2007. A Review of the Stakeholder Theory. In A. Geare, ed. Otago Management Graduate Review 5,17-26. Department of Management, University of Otago.

European Commission, 2000. EU Trade Concessions to Least Developed Countries: Everything but Arms Proposal. Possible Impacts on the Agricultural Sector, Brussels. available from http://www2.weed-online.org/eu/texte/first_eba_ias.pdf [accessed on 11 January 2013].

European Commission, 2012. Renewable Energy: a major player in the European energy market. available from http://ec.europa.eu/energy/renewables/doc/communication/2012/comm_en.pdf accessed on 3 January 2013].

European Commission, 2006. Upgrading the EU Investment Policy., (May), pp.1-4. available from http://www.iisd.org/pdf/2006/tas_upgrading_eu.pdf [accessed 10 January 2013].

Fairhead, J., Leach, M., Scoones, I., 2012. Green Grabbing: a new appropriation of nature? Journal of Peasant Studies 39(2), 237-261. 
FAO, 2009. How to Feed the World in 2050, available from http://www.fao.org/fileadmin/templates/wsfs/docs/expert_paper/How_to_Feed_the_World_ in_2050.pdf [accessed on 20 January 2013].

FIAN International, 2010. Land grabbing in Kenya and Mozambique:A report on two research missions - and a human rights analysis of land grabbing, 69115 Heidelberg, Germany.

Franco, J., Mehta, L. \& Veldwisch, G.J., 2013. The Global Politics of Water Grabbing. Third World Quarterly. 34(9), 1651-1675

Freeman, R.E., 1984. Strategic management 1st ed., Copp Clark Pitman, Toronto: Associated Companies.

Freeman,R.E., 1994. The Politics of Stakeholder Theory: Some Future Directions. Business Ethics Quarterly 4(4), 409.

Friedman, A.L., Miles, S., 2002. Developing Stakeholder Theory. Journal of Management Studies 39(1), 1-21.

Galaty, B.J.G., 2012. “Unused ” Land and Unfulfilled Promises : Justifications for Displacing Communities in East Africa Global Land Grabbing II. Paper presented at the International Academic Conference on Global Land Grabbing II, 1-14.

Ganho, P.W., A.S., 2011. Is Water the Hidden Agenda of Agricultural Land Acquisition in subSaharan Africa? Global Land Grabbing. In Global Land Grabbing. Land Deal Politics Initiative (LDPI) in collaboration with the Journal of Peasant Studies and hosted by the Future Agricultures Consortium at the Institute of Development Studies, University of Sussex.

Gardner, James R. Robert Rachlin, H.W.A.S., 1986. Handbook of Strategic Planning, 99th ed., New York: John Wiley \& Sons. 
Gobena, M., 2010. Effects of Large-scale Land acquisition in Rural Ethiopia: The Case of BakoTibe Woreda Thesis No xx. Swedish University of Agricultural Sciences, Sweden Examiner

Graham, A., Aubry, S., Künnemann, R., 2011. The Role of the EU in Land Grabbing in Africa CSO Monitoring 2009-2010 “Advancing African Agriculture” ( AAA ): The Impact of Europe's Policies and Practices on African Agriculture and Food Security Global Land Grabbing. Paper presented at the International Conference on Global Land Grabbing I

GRAIN, 2008. The 2008 land grab for food and financial security, available from http://www.grain.org/system/old/briefings_files/landgrab-2008-en.pdf [accessed on 20 January 2013].

GRAIN, 2012. Who 's behind the land grabs?A look at some of the people pursuing or supporting large farmland grabs around the world, 08010 Barcelona, Spain.

Hall, R., 2011. Land grabbing in Southern Africa: the many faces of the investor rush. Review of African Political Economy 38(128),193-214.

Harvey, D., 2003. The New Imperialism, Great Clarendon Street, Oxford OX2 6DP: Oxford University Press.

Hillman, A.M.Y.J., 2001. Stakeholder value, stakeholder management, and social issues: What is the bottom line? Strategic Management Journal 22(2), 125-139.

IFAD, 2011. Enabling poor rural people to overcome poverty, Rural Poverty Report 2011, 00142 Rome, Italy.

ILC, 2014. Internation Year of Family Farming IYFF-2014: Feeding the World. Caring for the Earth. 2014 The International Year of Family Farming, (January), available from http://www.familyfarmingcampaign.net/archivos/comunicacion/_poster_cientificoen.pdf [accessed on 17 January, 2013] 
James, G., Robert, R., Allen, S., 1986. Handbook of Strategic Planning, 99th ed., New York: John Wiley \& Sons.

Jawahar, I.M.M.L.G., 2001. Twards a descriptive stakeholder theory. The Academy of Management Review 26(3), 397-414.

Jonker, J., Foster, D., 2002. Stakeholder excellence? Framing the evolution and complexity of a stakeholder perspective of the firm. Corporate Social Responsibility and Environmental Management 9(4), 187-195.

Kay, S., Franco, J., 2012. The global water grab, a primer, Amsterdam, The Netherlands. available from http://www.tni.org/sites/www.tni.org/files/download/watergrabbingprimeraltcover2.pdf [accessed on 14 December 2012] .

Klaus Deininger, Derek Byerlee, Jonathan Lindsay, A.N., Harris Selod, M.S., 2011. Rising global interest in farmland, can it yield sustainable and equitable benefits?, $1818 \mathrm{H}$ Street NW, Washington DC 20433: The World Bank.

Austen, S., Seymour, R., Brown, K., Furneaux, C., McCabe, A., 2006. Multi-Outcome Construction Policies : Literature Review on Stakeholder Theory, Brisbane Qld 4000, Australia.

Lim, G., Ahn, H., Lee, H., 2005. Formulating strategies for stakeholder management: a casebased reasoning approach. Expert Systems with Applications 28(4), 831-840.

Margulis, M.E., McKeon, N., Borras, S.M., 2013. Land Grabbing and Global Governance: Critical Perspectives. Globalizations 10(1), 1-23. A

Mason, C., Kirkbride, J., Bryde, D., 2007. From stakeholders to institutions: the changing face of social enterprise governance theory. Management Decision 45(2), 284-301. 
McCarthy, J., 2010. Processes of inclusion and adverse incorporation: oil palm and agrarian change in Sumatra, Indonesia. The Journal of peasant studies 37(4), 821-50.

McDermott, M.C., Chan, K.C., 1996. Flexible intelligent relationship management: the business success paradigm in a stakeholder society. The Learning Organization, 3(3), 5-17.

McMichael, P., 2013. Land Grabbing as Security Mercantilism in International Relations. Globalizations 10(1), 47-64.

Mehta, L., Veldwisch, G.J. \& Franco, J., 2012. Introduction to the Special Issue: Water Grabbing? Focus on the (Re) appropriation of Finite Water Resources. Water Alternatives. 5(2),193-207

Miles, S., 2012. Stakeholder: Essentially Contested or Just Confused? Journal of Business Ethics 108(3), 285-298.

Mitchell, R.K., Agle, B.R., Wood, D.J., 1997. Toward a theory of stakeholder identification and salience: Defining the principle of who and what really counts. The Academy of Management Review 22(4), 853-886.

Mitta, shepard daniel with anuradha, 2009. The Great Land Grab: Rush for World's Farmland Threatens Food security for the Poor M. Moore, ed., oakland, ca 94619, USA: The Oakland Institute.

Ochieng, J., 2011. Kenya: Dominion Farms chief fears for his life. The global rush for farm land and peoples' struggles against it, available from http://farmlandgrab.org/19284 [accessed on 9 October 2012].

Oxfam International, 2011. Land and power wave of investments in land, Oxford, OX4 2JY, UK: Odfam International. 
Oya, C., 2013a. Methodological reflections on 'land grab' databases and the 'land grab' literature 'rush'. J. Peasant Stud. 40(3), 503-520.

Oya, C., 2013b. The Land Rush and Classic Agrarian Questions of Capital and Labour : a systematic scoping review of the socioeconomic impact of land grabs in Africa. Third World Quarterly. 34(9), 1531-1557.

Peluso, N.L., Lund, C., 2011. New frontiers of land control: Introduction. Journal of Peasant Studies 38(4), 667-681.

Pouloudi, A., 1999. Aspects of the Stakeholder Concept and their Implications for Information Systems Development. In Proceedings of the 32nd Hawaii International Conference on System Sciences - 1999. Hawaii: Maui HI, pp. 1-17.

Rowley, T.J., 1997. Moving beyond Dyadic Ties: A Network Theory of Stakeholder Influences. The Academy of Management Review 22(4), 887.

Rulli, M.C. \& D'Odorico, P.D., 2013a. The politics of evidence : a response to Rulli and D’Odorico. J. Peasant Stud. 40(5), 913-914.

Rulli, M.C. \& D'Odorico, P.D., 2013b. The science of evidence : the value of global studies on land rush. J. Peasant Stud. 40(5), 907-909.

Scoones, I., Hall, R., Borras S., White, B., Wolford, W., 2013. The politics of evidence: methodologies for understanding the global land rush. J. Peasant Stud. 40(3), 469-483

Snider, J., Hill, R.P., Martin, D., 2003. Corporate Social Responsibility in the 21st Century: A View from the World's Most Successful Firms. Journal of Business Ethics 48(2), 175-187.

Thaler, K., 2013. Large-scale land acquisitions and social conflict in Africa. In Food Sovereignty: A Critical Dialogue. International Conference, Yale University, September 14-15, 2013. 1-15. 
Transnational Institute, 2012. The European Union and the Global Land Grab, available from http://www.tni.org/sites/www.tni.org/files/download/european_union_and_the_global_land _grab-a5.pdf [accessed on 20 October 2012].

UNCHS, 2001. Tools to Support Participatory Urban Decision Making Urban Gove. D. McCallum, ed., Nairobi: United Nations Centre for Human Settlements - UNCHS (Habitat).

Ven, B., 2008. An Ethical Framework for the Marketing of Corporate Social Responsibility. Journal of Business Ethics 82(2), 339-352.

Visser, O. \& Spoor, M., 2011. Land grabbing in post-Soviet Eurasia: the world's largest agricultural land reserves at stake. Journal of Peasant Studies, 38(2), 299-323.

White, B., Borras, S.M., Hall, R., Scoones, I., Wolford, W., 2012. The new enclosures: critical perspectives on corporate land deals. J. Peasant Stud. 39(3-4), 619-647.

Wilkinson, J., Reydon, B., Di Sabbato, A., 2012. Concentration and foreign ownership of land in Brazil in the context of global land grabbing. Canadian Journal of Development Studies/Revue canadienne d'études du développement, 33(4), 417-438.

Winkler, I., 2009. Stakeholder salience in corporate codes of ethics using legitimacy , power, and urgency to explain stakeholder. Electronic Journal of Business Ethics and Organization Studies 14(1), 4-13.

Wolford, W., Borras, S.M., Hall, R., Scoones, I., White, B., 2013. Governing Global Land Deals : The Role of the State in the Rush for Land. Development and Change. 44(2),189210

World Bank, 2012. World Bank Group Investment Climate Advisory Services - Activities Related to Land, Annex 2: World Bank Group Statement on Oxfam Report, "Our Land, Our 
Lives," available from https://www.wbginvestmentclimate.org/donor-partners/upload/2013IC-FIAS-and-Land.pdf [accessed on 3 February 2013].

Zoomers, A., 2010. Globalisation and the foreignisation of space: seven processes driving the current global land grab. Journal of Peasant Studies 37(2), 429-447. 